\title{
Neuron Death in the Substantia Nigra of Weaver Mouse Occurs Late in Development and Is Not Apoptotic
}

\author{
Tinmarlar F. Oo, ${ }^{1}$ Richard Blazeski, ${ }^{2}$ Susan M. W. Harrison, ${ }^{3}$ Claire Henchcliffe, ${ }^{1}$ Carol A. Mason, ${ }^{2}$ \\ Suzanne K. Roffler-Tarlov, ${ }^{3}$ and Robert E. Burke ${ }^{1}$ \\ ${ }^{1}$ Department of Neurology, and 2Departments of Pathology, and Anatomy and Cell Biology, Center for Neurobiology and \\ Behavior, College of Physicians and Surgeons, Columbia University, New York, New York 10032, and ${ }^{3}$ Departments of \\ Neuroscience, and Anatomy and Cell Biology, Tufts University, Boston, Massachusetts 02111
}

Weaver is a spontaneous mutation in mice characterized by the postnatal loss of external granule cells in the cerebellum and dopaminergic neurons of the midbrain, especially in the substantia nigra. We have shown previously that natural cell death with the morphology of apoptosis occurs in the substantia nigra of normal rodents during postnatal development. We therefore sought to determine whether the loss of dopaminergic neurons in homozygous weaver mice occurs during the period of natural cell death in the substantia nigra and whether it has the morphology of apoptosis. We have found, using a silver stain technique, that although apoptotic cell death does occur early postnatally in homozygous weaver substantia nigra, it also does so with equal magnitude in wild-type and heterozygous weaver littermates. Unique to homozygous weavers is the occurrence of degenerating neurons in the nigra that are not apoptotic. These degenerating neurons are observed at postnatal day 7, and they are most abundant on postnatal days 24-25. The nonapoptotic nature of this cell death is confirmed by negative in situ end labeling of nuclear DNA fragmentation and by ultrastructural analysis. Ultrastructural studies reveal irregular chromatin aggregates in the nucleus, as well as marked cytoplasmic changes, including the formation of vacuoles and distinctive stacks of dilated cisternae of endoplasmic reticulum. We interpret these changes as indicative of either a variant morphology of programmed cell death or a pathological degenerative process mediated by an as yet unknown mechanism related to the recently described mutation in the GIRK2 potassium channel.

Key words: weaver; apoptosis; programmed cell death; substantia nigra; potassium channel; development; ultrastructure
Weaver $(w v)$ is a spontaneous autosomal recessive murine mutation that affects cells in cerebellum, midbrain, and testes. Abnormal cerebellar development and loss of cerebellar granule cells were noted early in the study of weaver mice (Sidman et al., 1965; Rezai and Yoon, 1972; Rakic and Sidman, 1973). Granule cell death has been identified in $w v / w v$ as early as postnatal day (P) 1 , and it is morphologically characterized by the appearance of rounded and distinctly bound chromatin clumps (Smeyne and Goldowitz, 1989), typical for those described in apoptosis (Kerr et al., 1972). Recent ultrastructural (Migheli et al., 1995) and in situ end labeling studies (Harrison and Roffler-Tarlov, 1995; Wullner et al., 1995) also indicate that this cell death is apoptotic.

Abnormalities of the dopaminergic system in $w v / w v$ were first observed by Lane and coworkers (1977), who noted a 50\% depletion of brain dopamine. Schmidt et al. (1982) subsequently demonstrated abnormalities in mesencephalic dopaminergic systems, including decreases in tyrosine hydroxylase (TH) activity in striatum, and a hypocellular substantia nigra pars compacta ( $\mathrm{SNpc}$ ). These abnormalities of mesencephalic dopaminergic systems are selective. The mesolimbic system, which arises from the ventral

Received May 30, 1996; revised July 11, 1996; accepted July 15, 1996.

This work was supported by National Institutes of Health Grants NS26836 (R.E.B.), NS16951 (C.A.M.), NS20181 (S.K.R.-T.), Program Project NS30532, and the Parkinson's Disease Foundation. We are grateful to Ms. Pat White for diligent secretarial assistance. We are also grateful to Drs. P. G. H. Clarke, V. Tennyson, J. Goldman, and A. P. Hayes for assistance in the interpretation of the electron micrographs, and to Dr. Art Tischler for technical assistance and advice.

Correspondence should be addressed to Dr. Robert E. Burke, Box 67, Department of Neurology, College of Physicians and Surgeons, Columbia University, 710 West 168th Street, New York, NY 10032.

Copyright (C) 1996 Society for Neuroscience $0270-6474 / 96 / 166134-12 \$ 05.00 / 0$ tegmental area and projects to the ventral striatum, is relatively spared compared with the nigrostriatal system, which arises from the substantia nigra (SN) and projects to the dorsal striatum (Roffler-Tarlov and Graybiel, 1984; Roffler-Tarlov and Graybiel, 1986). Even within the nigrostriatal system, there is selectivity for the defect; the nigrostriatal projection to striosomes initially appears intact, but later regresses, whereas the projection to the striatal matrix never develops normally (Roffler-Tarlov and Graybiel, 1987). This selectivity is also observed within the SN, where there is more pronounced loss of striosome-projecting dopaminergic neurons of the ventral tier than matrix-projecting neurons of the dorsal tier (Graybiel et al., 1990), and where neurons of the "dense zone" disappear later than other neurons (Roffler-Tarlov et al., 1996).

Little is known about the nature of dopamine neuron loss in SN in $w v / w v$. Numbers of TH-positive neurons in the midbrains of homozygous weavers are normal on P7 (Roffler-Tarlov et al., 1996). Several studies show that most of the vulnerable sets of TH-positive neurons disappear by the end of the third postnatal week (Triarhou et al., 1988; Roffler-Tarlov et al., 1996). Although it is clear that there is a loss of expression of the TH-positive phenotype, the relationship of this decrement to the actual occurrence of degeneration is unknown.

We have previously observed that natural cell death, with the morphology of apoptosis, occurs during the postnatal development of rat (Janec and Burke, 1993) and that it is inducible by early injury to the striatal target (Macaya et al., 1994). Based on the observation that impaired striatal dopaminergic terminal function, assessed by dopamine reuptake, is one of the 
earliest abnormalities observed in the $w v / w v$ nigrostriatal system (Roffler-Tarlov et al., 1990), and that such an abnormality may impair the maintenance of target-derived support, we hypothesized that the $w v$ mutation may be associated with augmented apoptotic cell death in SN. We have found, however, that although apoptosis does occur in postnatal $w v / w v \mathrm{SN}$, it occurs with equal magnitude in the $+/ w v$ and $+/+$ mice. Unique to $w v / w v, \mathrm{SN}$ is the later occurrence of neuronal degeneration with a nonapoptotic morphology.

\section{MATERIALS AND METHODS}

Animals. All mice were offspring of either $+/ w v$ or $+/+$ breeding pairs supplied by the Jackson Laboratory (Bar Harbor, ME) and bred and maintained in the laboratory colony (SKR-T, SH). All mice were on a $\mathrm{C}_{57} \mathrm{Bl} / 6 \mathrm{JLe}-\mathrm{A}^{\mathrm{wj}} \times \mathrm{CBA} / \mathrm{CaGnLeF}$ hybrid background. Identification of phenotype as $+/+,+/ w v$, or $w v / w v$ was based on examination of behavior and postmortem examination of cerebellum, as described previously (Roffler-Tarlov and Turey, 1982). The day of birth was defined as P0.

Silver staining. To demonstrate cell death and to characterize its morphology, consecutive sections from the SN and striatum were silverstained (Gallyas et al., 1980). At selected postnatal ages, mice were anesthetized with Nembutal and then perfused through the left ventricle with $0.9 \%$ saline at $4{ }^{\circ} \mathrm{C}$, followed by perfusion with $4 \%$ paraformaldehyde in $0.1 \mathrm{M}$ phosphate buffer, $\mathrm{pH} 7.2$, for $20 \mathrm{~min}$. Brains were carefully removed from the skull and post-fixed in the same fixative for at least 1 week. Blocks were then cryoprotected by immersion in $20 \%$ sucrose $/ 4 \%$ paraformaldehyde/ $0.1 \mathrm{~m}$ phosphate buffer overnight. Blocks were rapidly frozen in 2-methylbutane chilled on dry ice and sectioned in a cryostat at $30 \mu \mathrm{m}$. Representative sections through the entire SN and striatum were obtained and processed for silver staining. Sections were maintained in serial order and processed free-floating in custom-made plastic grids with nylon mesh bottoms. Sections were collected into cold fixative, washed 3 times in distilled water, and then immersed in pretreating solution (equal volumes $9 \% \mathrm{NaOH}$ and $1.2 \% \mathrm{NH}_{4} \mathrm{NO}_{3}$ ) for 5 min twice. They were then immersed in impregnating solution $(60 \mathrm{ml}$ of $9 \% \mathrm{NaOH} ; 40 \mathrm{ml}$ of $16 \%$ $\mathrm{NH}_{4} \mathrm{NO}_{3} ; 0.5 \mathrm{ml}$ of $50 \% \mathrm{AgNO}_{3}$ ) for $10 \mathrm{~min}$. Sections were then washed 3 times in washing solution ( $1 \mathrm{ml}$ of $1.2 \% \mathrm{NH}_{4} \mathrm{NO}_{3}$ added to $100 \mathrm{ml}$ of a solution containing $5 \mathrm{gm}$ anhydrous $\mathrm{Na}_{2} \mathrm{CO}_{3}, 300 \mathrm{ml}$ of $95 \%$ ethanol, brought to 11 with distilled water) followed by immersion in developing solution ( $1 \mathrm{ml}$ of $1.2 \%$ of $\mathrm{NH}_{4} \mathrm{NO}_{3}$ and $100 \mathrm{ml}$ of a solution consisting of $0.5 \mathrm{gm}$ citric acid in $15 \mathrm{ml}$ of $37 \%$ formalin, $100 \mathrm{ml}$ of $95 \%$ ethanol, 700 $\mathrm{ml}$ of water brought to $\mathrm{pH} 5.8-6.1$ with $9 \% \mathrm{NaOH}$, and finally brought to 11 with water). Sections were kept in developing solution for $\geq 1 \mathrm{~min}$. Sections were then mounted on subbed slides, air dried, and immersed in $0.5 \%$ acetic acid 3 times for $10 \mathrm{~min}$ each. Sections were then dehydrated through alcohols, cleared in xylene, and coverslipped under Permount.

Quantitative morphological analysis of silver-stained sections. At P7, all available SN silver-stained sections were analyzed (mean number of sections per animal $=13.3$ ). For older mice, the SN was divided into three caudorostral regions: (1) a caudal region containing the medial lemniscus and the interpeduncular nucleus; (2) a central region containing the medial terminal (MT) nucleus of the accessory optic tract; and (3) a region anterior to MT, containing a well defined SNpc. Each of these regions was sampled with three to five sections (mean number of sections per animal P14-adult $=$ $12.8 \pm 0.3$ ). Within each section, the $\mathrm{SN}$ on one side was scanned at $600 \times$ over its entire medial-to-lateral extent. The boundaries of the SN were identified by cytoarchitectonic features and information from THimmunostained sections available from earlier studies (SKR-T). Apoptotic profiles were identified and counted based on the presence of one or more intensely silver-stained chromatin clumps surrounded by a cellular profile. Examples are shown in Figure 1. Bare chromatin clumps, not surrounded by a cell profile, were not counted because more than one clump can disperse from a single disintegrating cell.

We used stereological concepts to quantify the number of apoptotic profiles per section in each of the three genotypes (Coggeshall, 1992). Our approach was based on the principal of the optical dissector, which can be used in thick sections (Gundersen, 1986) by utilizing a threedimensional assessment of each profile in the section. Each identified profile was examined by focusing up to ascertain that the top of the profile was contained within the section (Coggeshall and Lekan, 1996). In performing this three-dimensional assessment, we observed that profiles with tops in the section also always had a bottom in the section. Clark and Oppenheim (1995) have noted in paraffin-embedded sections cut at 8-12 $\mu \mathrm{m}$ that apoptotic profiles rarely $(1-2 \%)$ are identified in strictly adjacent serial sections. We have made similar observations in $20 \mu \mathrm{m}$ frozen sections for apoptotic profiles in SN in developing rat (our unpublished observations). These observations would suggest that apoptotic profiles are rarely recognizable as split. This may occur because the profile is not readily bisected by the advancing knife, or because the complex visual criteria used to identify the profiles rarely allow a single profile to meet criteria on both sections whenever split. In any case, in our material there was an exact correspondence between profiles and counted tops, so we have expressed our raw count data as apoptotic cells per section. For each animal, the number of apoptotic cells per section from all sections was averaged to give an overall value for the number of apoptotic cells per section for that animal. We also measured the size of apoptotic profiles identified by silver staining in the three genotypes. This was done by coupling a Nikon Labophot microscope to a Dage 81 Series video camera, digitizing profiles under a $60 \times$ objective, and determining area using a Loats Associates Inquiry image analysis system.

TH immunostaining. P21-P24 mice ( $w v / w v, n=2 ;+/ w v, n=5 ;+/+$, $n=1$ ) were fixed by perfusion as described for silver staining, and the brains were post-fixed for 1-2 weeks. Cryostat-cut sections $(30 \mu \mathrm{m})$ were taken through the $\mathrm{SN}$ and incubated overnight at $4^{\circ} \mathrm{C}$ with a mouse monoclonal anti-TH antibody (Boehringer-Mannheim) at 1:10 in PBS/ $10 \%$ horse serum, followed by incubations with biotinylated horse antimouse IgG (Vector) at $1: 50$ in $\mathrm{PBS} / 10 \%$ horse serum, and then with avidin-biotinylated horseradish peroxidase complexes (ABC Kit, Vector) at 1:600 at room temperature for $1 \mathrm{hr}$. Sections were then incubated with diaminobenzidine (Aldrich) $(50 \mathrm{mg} / 100 \mathrm{ml} \mathrm{Tris,} \mathrm{pH}$ 7.6) in the presence of $\mathrm{H}_{2} \mathrm{O}_{2}$. The sections were Nissl-counterstained and examined at $600 \times$.

In situ end labeling. P2 $4 w v / w v$ and $+/+$ mice were deeply anesthetized with Nembutal and transcardially perfused with $15 \mathrm{ml}$ of $37^{\circ} \mathrm{C}$ heparinprocaine-saline solution $(20 \mathrm{U} / \mathrm{ml}$ heparin, $5 \mathrm{mg} / \mathrm{ml}$ procaine- $\mathrm{HCl}, 0.9 \%$ $\mathrm{NaCl}$ ). This was followed by transcardial perfusion of $35 \mathrm{ml}$ of Bouin's fixative. Brains were removed and immersion-fixed in Bouin's fixative overnight at room temperature. Brains were dehydrated, cleared, and paraffin-embedded using standard procedures. Ten-micrometer-thick serial sections were cut, and one section of every five was mounted on glass slides in Elmer's glue and water. Slides were dried overnight at $42^{\circ} \mathrm{C}$. Sections were deparaffinized, rehydrated through a graded series of ethanols, and washed in water. Slides were either air dried and stored until used or used immediately for in situ end labeling. Sections were treated for $7.5 \mathrm{~min}$ with freshly prepared $40 \mathrm{mg} / \mathrm{ml}$ Proteinase K (Boehringer Mannheim) at room temperature. Positive control sections were treated with $40 \mathrm{U} / \mathrm{ml} \mathrm{RNase-free} \mathrm{DNase} \mathrm{(Sigma)} \mathrm{for} 15 \mathrm{~min}$ at $37^{\circ} \mathrm{C}$. The terminal transferase reaction was performed using $20 \mu \mathrm{M}$ biotin-14deoxycytosine triphosphate (dCTP) (Life Technologies) and $240 \mathrm{U} / \mathrm{ml}$ terminal deoxynucleotidyl transferase (United States Biochemicals/Amersham) in a cacodylic acid buffer for $1 \mathrm{hr}$ at $37^{\circ} \mathrm{C}$. Negative control sections were incubated without terminal transferase. Sections were blocked with $2 \%$ bovine serum albumin (Sigma) for $10 \mathrm{~min}$ at room temperature and incubated with streptavidin conjugated to $\beta$-galactosidase diluted 1:1000 (Boehringer Mannheim) for $30 \mathrm{~min}$ at room temperature. The biotin-dCTP, avidin- $\beta$-gal conjugates were detected by incubation of the sections with $0.075 \% \mathrm{X}$-gal for $1 \mathrm{hr}$ at $37^{\circ} \mathrm{C}$. Sections were counterstained with Contrast Red (Kirkegaard and Perry Laboratories). Adjacent sections were immunostained for $\mathrm{TH}$ using a microwave antigen retrieval protocol (Tischler, 1995). Sections were deparaffinized and rehydrated, and microwaved in $0.01 \mathrm{~m}$ citrate buffer, $\mathrm{pH} 6$, for two $5 \mathrm{~min}$ pulses, separated and followed by $5 \mathrm{~min}$ resting periods. Sections were sequentially incubated with a mouse monoclonal anti-TH antibody (1:250) (Incstar) overnight at $4^{\circ} \mathrm{C}$, and a biotinylated goat anti-rabbit IgG antibody (1:200) (Vector) for $1 \mathrm{hr}$ at room temperature. Sections were then incubated with avidin-biotin-peroxidase complex (ABC Elite Kit, Vector) for $1 \mathrm{hr}$ at room temperature. Sections were incubated with diaminobenzidine at room temperature.

Electron microscopy. For ultrastructural studies, three $w v / w v$ and three $+/+$ mice were perfused at P24 with $3 \%$ glutaraldehyde in 0.1 M Sorensen's buffer and post-fixed for 1 week. Sections through the SN were cut on a vibratome at $100 \mu \mathrm{m}$ and collected into $0.1 \mathrm{M}$ Sorensen's buffer. Sections were stained in $1 \% \mathrm{OsO}_{4} / 0.1 \mathrm{~m}$ Sorensen's for $60 \mathrm{~min}$, and then washed. After dehydration in ascending concentrations of alcohols, sections were embedded in Epox between two plastic slides. The sections were then trimmed to include the medial portion of the SNpc, mounted on an Epon stub, and cut at $10 \mu \mathrm{m}$ for examination under phase contrast. Sections of interest were then reembedded, thin-sectioned, and examined on a JEOL $1200 \mathrm{EX}$ electron microscope. 

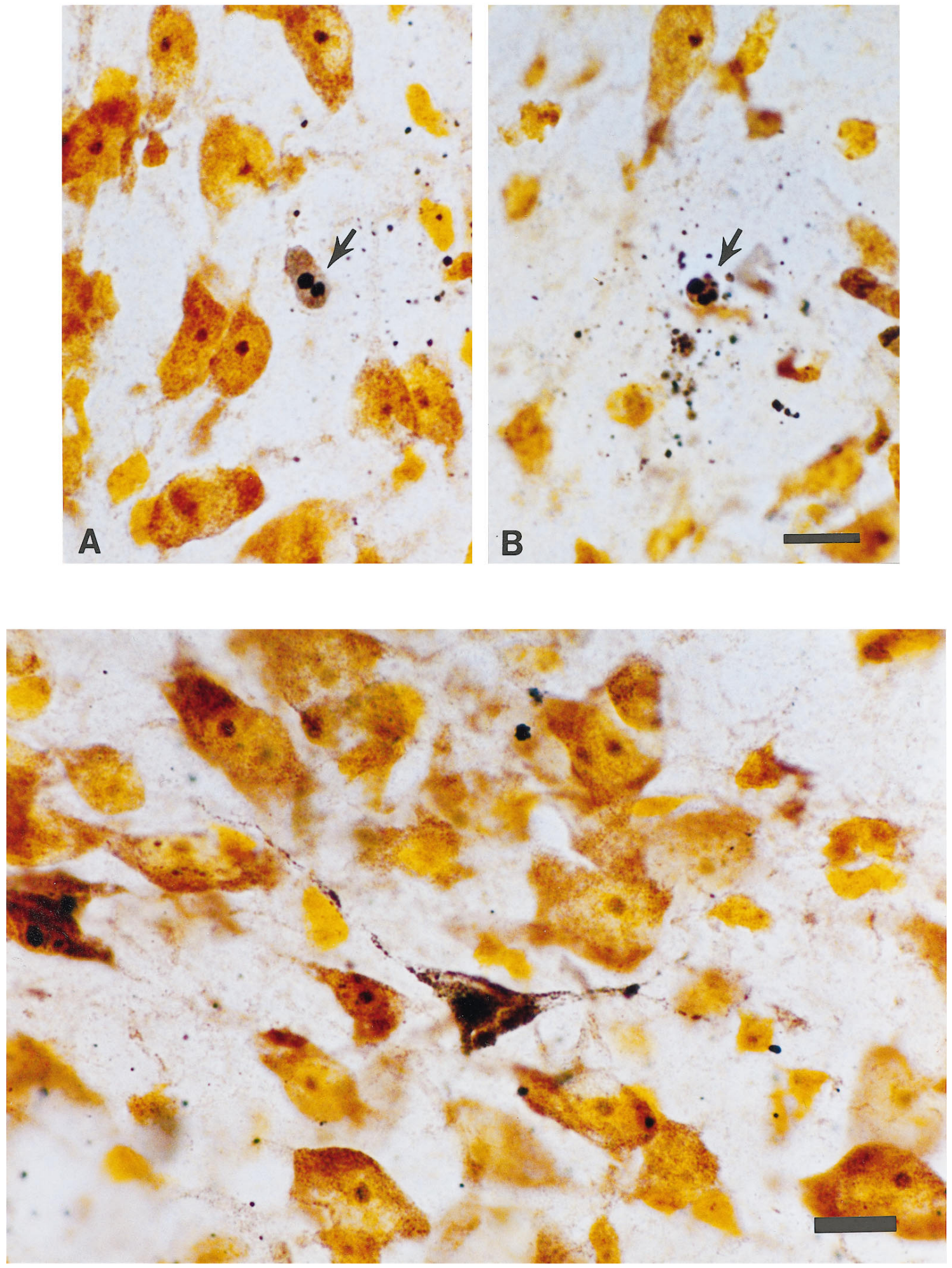

Figure 1. Top. A, An example of an apoptotic profile, demonstrated by silver staining, in the SNpc of a wv/wv mouse at P7 (arrow). Characteristic of apoptosis are the two darkly silver-impregnated, rounded chromatin clumps. The chromatin clumps are surrounded by a moderately silver-impregnated cellular profile. The dark silver impregnation of the apoptotic profile contrasts with the golden hue of adjacent, normal neurons. $B$, An example of an apoptotic profile in the SNpc of a $+/ w v$ mouse at P14 (arrow). This particular profile is somewhat smaller than the profile shown in $A$, as it appears to be undergoing some breakup (there is scattered adjacent silver-stained material), but it is otherwise similar in its basic features: there are darkly impregnated, rounded chromatin clumps surrounded by a less intensely silver-impregnated, rounded cellular profile. Scale bar, $10 \mu \mathrm{m}$.

Figure 3. Bottom. An example of a silver-stained, nonapoptotic neuronal profile demonstrated in the SNpc of a $w v / w v$ mouse at P14. This silver-impregnated profile contrasts with the apoptotic profiles demonstrated in Figure 1 in several respects. There are no distinct chromatin clumps; rather, the entire nucleus is darkly impregnated. Rather than being rounded and faintly silver-impregnated, the surrounding cytoplasm retains a polygonal, neuronal appearance and is heavily silver-impregnated. The appearance of long and heavily impregnated neuronal processes, with bifurcations, would be distinctly unusual for an apoptotic neuronal profile, and yet was observed universally in these cells. Scale bar, $10 \mu \mathrm{m}$. 


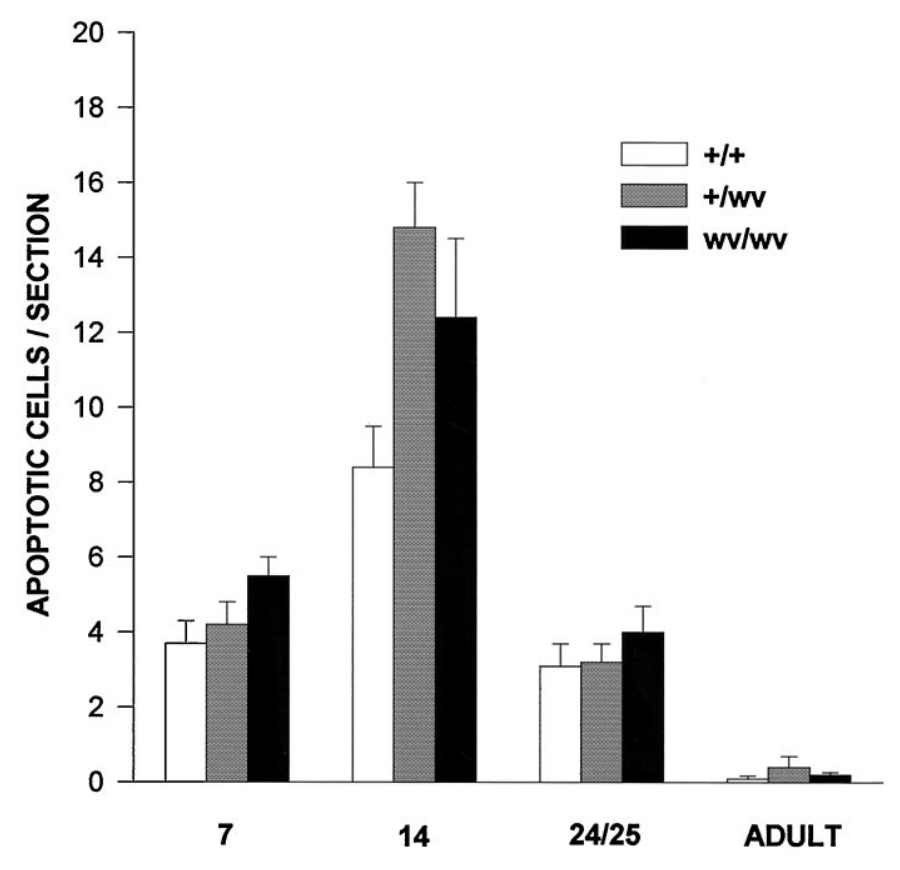

POSTNATAL DAY

Figure 2. Quantitative analysis of the number of silver-stained apoptotic profiles in $w v / w v,+/ w v$, and $+/+$ littermates at three developmental ages and in adults. At each age, and for each genotype, $n=4$ animals were analyzed, as described in Materials and Methods. ANOVA revealed a robust effect of age $(p<0.0001)$, with more cells present at P14 compared with other ages $(p<0.05$ Newman-Keuls post hoc $)$ and fewer in adulthood $(p<0.05)$. Although ANOVA revealed a marginally significant difference between $+/+$ and the other two genotypes $(p=0.02)$, this effect was entirely attributable to the difference noted at P14, and we cannot exclude other sources of variability related to silver staining contributing to this apparent difference. At no time was there any difference between $w v / w v$ and $+/ w v$.

\section{RESULTS}

\section{Light microscopy}

Silver impregnation identified degenerating cells in the $\mathrm{SN}$ in $w v / w v,+/ w v$, and $+/+$ with a morphology typical for apoptosis (Fig. 1). These cells were rounded and readily distinguished by their dark staining from normal neurons, which take on a golden hue after the Gallyas silver impregnation procedure. In addition, these cells demonstrated one or more intensely argyrophilic rounded and distinctly demarcated chromatin clumps, as described previously for apoptotic cell death in rat SN neurons during both natural (Janec and Burke, 1993) and induced (Macaya et al., 1994; Oo et al., 1995) cell death. In the latter settings, this chromatin clumping has been confirmed to be apoptotic in nature by both ultrastructural and end labeling analysis (Macaya et al., 1994; Oo et al., 1995). These cells were observed in all the mice at each age examined.

To determine whether a quantitative difference exists between $w v / w v$ and other genotypes in the level of apoptotic cell death at one or more postnatal ages, the prevalence of these cells was determined in representative SN sections obtained from each of the three genotypes. As shown in Figure 2, there was no consistent difference among the three genotypes in the numbers of these apoptotic profiles. Although formal ANOVA did suggest a minor difference between $+/+$ and the other two genotypes $(p=0.02)$, this effect was entirely attributable to a diminished number of profiles at P14 in the $+/+$ group; at no other time was there an apparent genotype effect. We cannot discount the possibility that the apparent difference at P14 was attributable to other sources of variability related to tissue processing. At no time was there a significant difference between $+/ w v$ and $w v / w v$, and there was no significant interaction between age and genotype. ANOVA did reveal a highly robust effect of age $(p<0.0001)$ on the prevalence of apoptotic cells, with more cells being present at P14 $(p<0.05$, Newman-Keuls post hoc analysis). In addition, the adult group differed from all others in the very small number of apoptotic profiles $(p<0.05$, post hoc). Both of these findings are similar to what we have reported previously for the time course of apoptotic cell death in rat SN (Janec and Burke, 1993). We conclude that the magnitude and time course of apoptotic cell death postnatally in $\mathrm{SN}$ in $w v / w v$ is not significantly different from $+/ w v$ and $+/+$ littermate controls.

We identified a small but significant difference between $w v / w v$ and littermates in the size of apoptotic profiles demonstrated by silver staining. The mean area of these profiles was $34.3 \pm 0.9 \mu \mathrm{m}^{2}$ in $w v / w v(n=88$ profiles $)$, whereas in $+/ w v$ and $+/+$ it was $30.1 \pm$ $0.6(n=88)$ and $31.5 \pm 0.7(n=88)$, respectively. This small $(14 \%)$ increase in the size of the $w v / w v$ profiles would not influence the analysis performed in Figure 2, which was based on a stereological assessment. If a traditional Abercrombie correction (Abercrombie, 1946) were applied to the data shown in Figure 2, the only change in the analysis would be that $+/+$ would not be less than both $w v / w v$ and $+/ w v$, and $+/ w v$ would be only marginally $(p<0.04)$ greater than $+/+$ and $w v / w v$. This analysis underscores our interpretation that the small differences in counts among the genotypes at P14 are unlikely to be relevant to the $w v / w v$ phenotype.

Examination of silver-impregnated sections revealed that darkly impregnated neuronal profiles, predominantly in SNpc (Fig. 3), were unique to $w v / w v$ mice at later postnatal ages. These impregnated profiles could be distinguished from apoptotic profiles in several respects. (1) The entire nucleus was darkly impregnated without the appearance of characteristic discrete, rounded chromatin clumps. (2) The cytoplasm was not shrunken and rounded, as is typical for apoptosis, but retained a polygonal, neuronal appearance, often with clear visualization of dendrites, including primary and secondary bifurcations. (3) The cytoplasm typically contained a dense, punctate silver impregnation. The time course of appearance of these degenerating neurons differed from that of apoptotic cell death, as shown in Figure 4. A few of these cells were apparent in $w v / w v$ at P7. A maximum number was observed at P24-P25. By adulthood, very few were present. In $+/+$ animals, these cells were never observed. In $+/ w v$ animals, few darkly impregnated neuronal profiles were observed in $\mathrm{SN}$ at P24-P25 and in adulthood.

The regional distribution of these nonapoptotic cells was examined in four $w v / w v$ mice at $\mathrm{P} 24-\mathrm{P} 25$. These nonapoptotic degenerating cells were most numerous in the medial region of the SNpc (the "dense zone"), but they were also found throughout the medial-to-lateral extent of the SNpc, and in the pars lateralis. In the rostrocaudal dimension, $50.5 \%$ of the nonapoptotic cells were located in the rostral-most SN planes. Another 37.8\% were located in the caudal-most planes, whereas only $11.8 \%$ were located in the central region. Although we did not count the number of $\mathrm{TH}$-positive cells in these regions, and therefore did not normalize counts of dying cells for the number of TH-positive neurons present, the number of dying cells appeared to parallel the density of TH-positive neurons in these regions. The vast majority (99\%) 


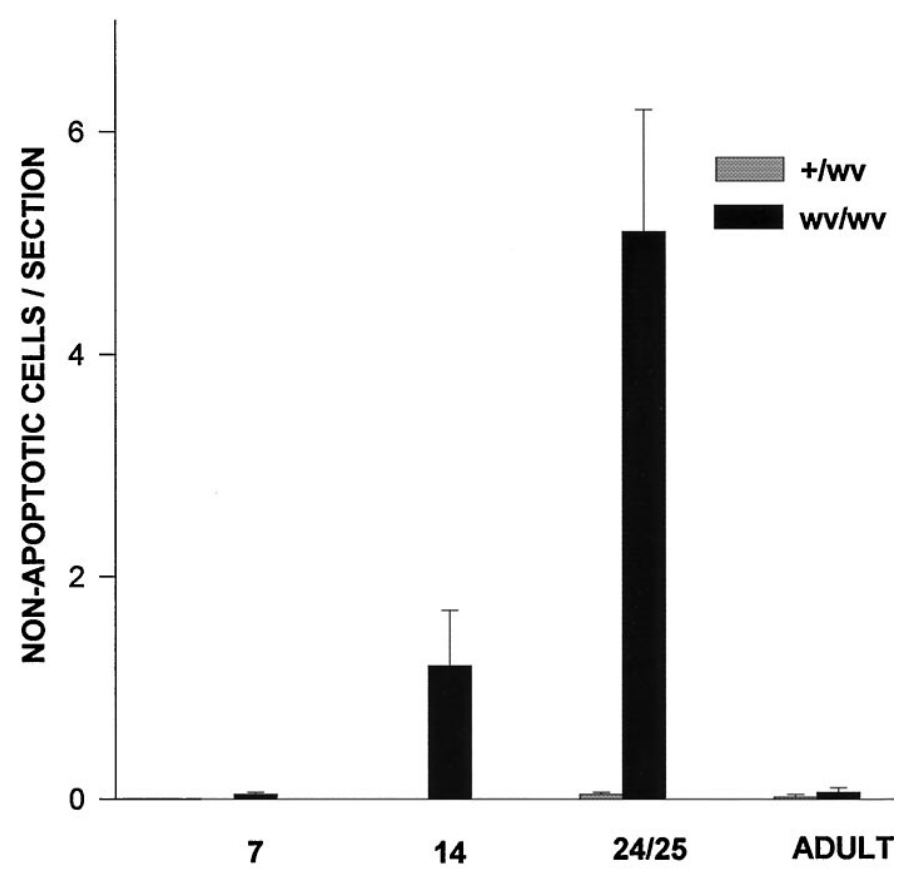

POSTNATAL DAY

Figure 4. Quantitative analysis of the number of silver-stained nonapoptotic profiles in $w v / w v$ and littermate controls at representative developmental ages. The same animals analyzed for apoptotic profiles, shown in Figure 2, have been analyzed here. Nonapoptotic profiles first appeared in $w v / w v$ at $\mathrm{P} 7$ and increased in number to become most numerous at P24-P25. These nonapoptotic profiles appeared almost exclusively in $w v / w v$. None was observed in $+/+$ animals, and only a few were observed in $+/ w v$ at $\mathrm{P} 24-\mathrm{P} 25$ and in adulthood.

of degenerating neurons was localized in the SNpc; only $1 \%$ were observed in SN pars reticulata (SNpr). Those in SNpr were found exclusively in caudal SN planes where TH-positive dopaminergic neurons of the ventral tier are known to reside. In the midbrain, nonapoptotic cells were not localized exclusively in the $\mathrm{SN}$; a number were also observed in the ventral tegmental area. Other nuclei of the basal ganglia with important anatomical relationships with the SN, including the striatum and the globus pallidus, were examined in $w v / w v$ animals at different postnatal ages, but nonapoptotic degenerating cells were not found.

To further characterize the nature of the cell death in $w v / w v$ SN at $\mathrm{P} 24-\mathrm{P} 25$, we performed an in situ $3^{\prime}$-end labeling procedure to identify the presence of fragmented nuclear DNA, a characteristic of apoptosis. As shown in Figure 5, and consistent with our assessment of the morphology revealed by silver stain, sections throughout the weavers' midbrains were without free $3^{\prime}$ ends, indicating a nonapoptotic form of cell death. This negative result was obtained in spite of our ability to demonstrate positive $3^{\prime}$-end labeling in $w v / w v$ cerebellum, where apoptosis does occur (Harrison and Roffler-Tarlov, 1995).

To attempt to define the dopaminergic phenotype of dying cells in SNpc, we performed TH immunostaining with Nissl counterstain. We have shown previously that this procedure successfully detects apoptotic cell death in these neurons, both during natural cell death (our unpublished observation) and induced cell death (Macaya et al., 1994; Oo et al., 1995). Presumably, therefore, the apoptotic death process is rapid enough to permit demonstration of retained cytoplasmic phenotypic markers. Accordingly, 2600
TH-positive neurons were examined on 14 sections obtained from the midbrain of a single P24 $w v / w v$ mouse. No TH-positive apoptotic cells were observed. In regions known to contain degenerating cells, identified on silver-stained adjacent sections, abnormal Nissl staining was observed among TH-negative neurons of the SNpc (Fig. 6). These cells contained pleiomorphic, basophilic chromatin aggregates, and a vacuolated "foamy" appearance of the cytoplasm. Thus, by this histological approach, as with end labeling, we were unable to demonstrate apoptotic cell death in $\mathrm{SNpc}$, but again observed morphological features of nonapoptotic degeneration.

\section{Electron microscopy}

The nonapoptotic morphology of the neuron death in $w v / w v$ at P24 was further confirmed by analysis at an ultrastructural level. Examples of degenerating cells observed in $w v / w v$ are shown at the light microscope level in Figure 7 and at the ultrastructural level in Figure 8, $A$ and $B$. Morphological alterations are observed in both the nucleus and the cytoplasm. The nuclei show an overall increase in electron density, the nuclear membrane is deeply invaginated, and there is dilatation of the perinuclear cisternal space (Fig. 8A,B). Moreover, the nuclear chromatin forms abnormal, irregularly shaped aggregates. These aggregates differ from those typically observed in apoptosis in that they are neither apposed to the nuclear membrane nor rounded with sharply demarcated edges (Sloviter et al., 1993; Macaya et al., 1994) (see Fig. 9C). The cytoplasm of these cells also shows an overall increase in electron density. In some of the cells, exemplified by the profile in Figure $8 A$, there were numerous, aggregated stacks of endoplasmic reticulum (ER). The cisternae of the ER were dilated, and the regions between cisternae were packed with aggregates of ribosomes (Fig. 8A, inset). Other cells, as shown in Figure $8 B$, displayed extensive vacuole formation. Some of the vacuoles were continuous with a dilated perinuclear space. As shown in Figure $8 B$ (inset), the vacuoles contained a loosely aggregated matrix, and they were surrounded by densely packed ribosomes. These abnormal features are readily contrasted with adjacent normal cells in $w v / w v$ SN (Fig. $9 A$ ) and normal cells in $+/+$ SN (Fig. 9B). These features can also be contrasted with an instance of apoptotic cell death in a $+/+$ animal at P24 (Fig. 9C). This cell shows features characteristic of the late stages of apoptotic cell death: formation of rounded, well demarcated, electron-dense chromatin clumps and an increase in the electron density of the cytoplasm, with relative preservation of mitochondria. Cells with the abnormal ultrastructural features shown in Figure $8, A$ and $B$, were not observed in $+/+$ animals.

We rarely observed abnormal cells in $w v / w v$ mice, which we believe may represent early stages of the degenerative process illustrated in Figure 8, $A$ and $B$. Such cells showed milder, but similar abnormalities. The cell shown in Figure 10 contains abnormal, irregular chromatin clumps in the center of the nucleus and adjacent to the nuclear membrane. There also is a slight increase in the electron density of the cytoplasm. Within the cytoplasm, rare vacuoles are seen, as well as aggregates of ER, associated with dense accumulations of ribosomes.

The neuronal nature of the degenerating cells in $w v / w v$ midbrains could be confirmed in some instances by the identification of synaptic densities, as shown in Figure 11.

\section{DISCUSSION}

The morphological appearance of apoptosis is so often observed in the course of programmed cell death that many investigators 

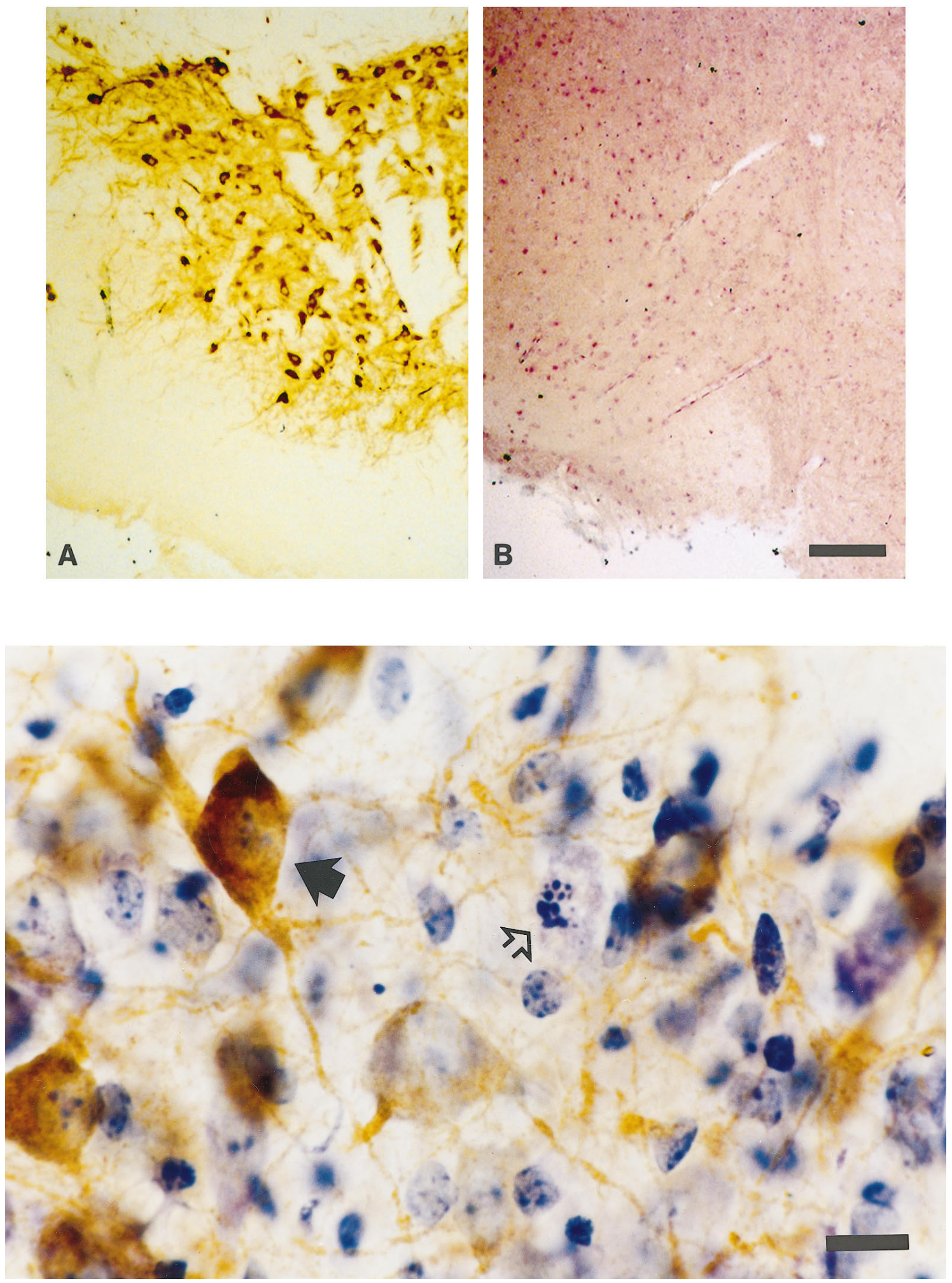

Figure 5. Top. In situ end labeling in a $w v / w v$ mouse. $A$, TH immunostain of a $\mathrm{P} 24 w v / w v$ mouse, demonstrating the medial portion of the SNpc. $B$, In situ end labeling of a region comparable to that shown in $A$, in a P24 $w v / w v$ mouse. There is an absence of blue X-gal staining over the SNpc, indicating a negative reaction for free $3^{\prime}$ ends. Scale bar, $100 \mu \mathrm{m}$.

Figure 6. Bottom. TH immunostain and Nissl counterstain of an $\mathrm{SN}$ section from a P24 wv/wv mouse. A normal-appearing, peroxidase-positive (brown) neuron is indicated (solid arrow). Note that the nucleus of this cell contains two stained heterochromatin clumps, characteristic of normal mouse cells (Moser et al., 1975). Adjacent to the TH-positive neurons is a TH-negative cell (open arrow) with a vacuolated, foamy-appearing cytoplasm, and an abnormal nucleus containing multiple, intensely basophilic, pleiomorphic chromatin aggregates of varying size. These aggregates differ from those observed in apoptosis in that they are greater in number, more diverse in their shape (rather than being simply rounded), and they are smaller. The chromatin aggregates in this micrograph can be compared with those typical for apoptosis shown at the same magnification in Figure 1. 

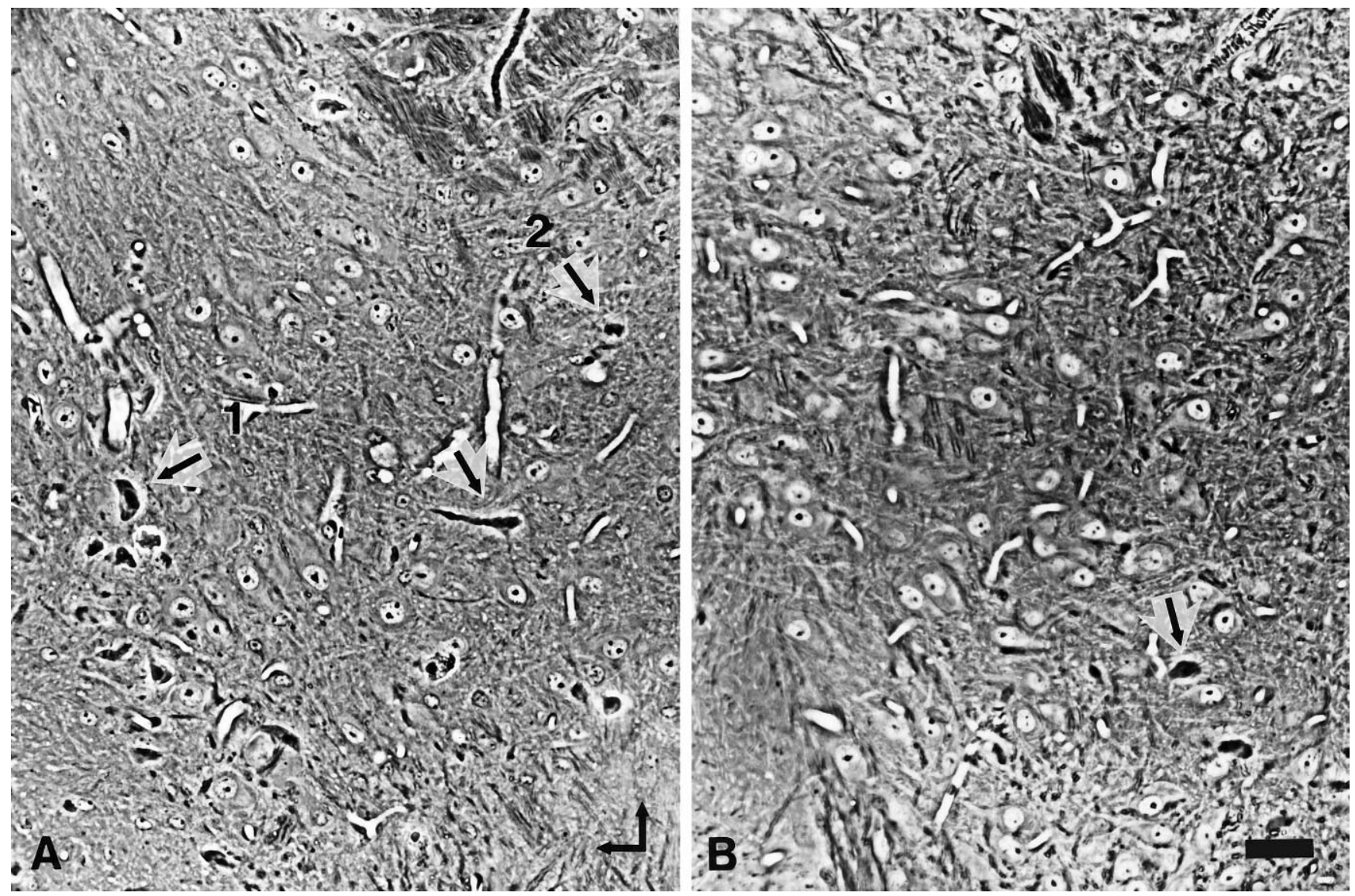

Figure 7. Numerous dark, osmium-stained abnormal cells are observed in $w v / w v$ SN. $A$, An osmium-stained plastic-embedded $10 \mu \mathrm{m}$ section of $w v / w v$ $\mathrm{SNpc}$ at $\mathrm{P} 24$, shown in phase contrast. Shown is the medial portion of SNpc (dorsal is indicated by an up arrow, lateral by a left arrow, lower right corner). Compared with the same region of $+/+\mathrm{SNpc}$ shown in $B$, there are fewer neurons in $w v / w v$. In $w v / w v$, there are numerous dark, osmium-stained degenerating neurons (indicated by black arrows within white arrows). The neurons labeled with the numbers 1 and 2 are shown at higher magnification in Figure 8. Each of the dark neurons in $w v / w v$ is surrounded by a bright rim of high illumination in phase. $B$, SNpc of $+/+$ at P24. Rare cells in SNpc were stained (black arrow within white arrow). A representative example is shown in Figure 9C. Scale bar, $100 \mu \mathrm{m}$.

use the terms synonymously. However, we will use the term apoptosis in its more restricted sense, to refer to one particular morphology of programmed cell death. Therefore, by interpreting the morphology of neuron degeneration in the SN to be "nonapoptotic," we do not mean to imply that this is not a form of programmed cell death; this remains a possibility, as discussed below. Our use of the term apoptosis to refer strictly to a morphological concept is based on the original use of the term (Kerr et al., 1972) and recognition of the fact that other, nonapoptotic morphologies are observed in programmed cell death (Clarke, 1990; Schwartz et al., 1993).

The strictest morphological criteria for identification of apoptosis in brain depend on ultrastructural observations. Distinctive features are observed both in the nucleus and cytoplasm, but those in the nucleus occur earlier and are most distinctive. The most characteristic alteration of nuclear morphology is the formation of sharply delineated, homogeneous, electron-dense chromatin masses (Kerr et al., 1995). The mere presence of intranuclear chromatin aggregates is not sufficient to identify apoptosis; irregular aggregates with poorly defined edges have been clearly identified in necrotic cell death (Olney, 1969; Kerr et al., 1995). The cytoplasmic features of apoptosis are also distinctive. Early, there is an overall condensation of the cell with an increase in its electron density, with preservation of intracellular organelles (such as mitochondria) and both nuclear and cellular membranes
(Kerr et al., 1995). Although not as definitive as ultrastructure, several methods at the light microscope level can be highly suggestive (Clarke and Oppenheim, 1995). Nissl stains have been used to identify the distinct, round chromatin clumps characteristic of apoptosis, and in many instances the ultrastructural features have been confirmed (Cunningham, 1982; Williams and Rakic, 1988; Ferrer et al., 1990; Sloviter et al., 1993; Macaya et al., 1994). Suppressed silver-staining methods also have been used to identify intensely argyrophilic, distinct, round chromatin clumps (Yamamoto et al., 1986; Janec and Burke, 1993; Macaya et al., 1994; Mitchell et al., 1994), and confirmed by ultrastructural analysis. Labeling of free 3' ends (Gavrieli et al., 1992) can also be highly suggestive of apoptotic cell death at the light microscope level, if it is used with strict attention to the morphological appearance of apoptosis (Oo et al., 1995).

We have used all of these approaches to identify the character of the neuron death in the $\mathrm{SN}$ of $w v / w v$ mice. Silver staining clearly demonstrated typical apoptotic morphology early postnatally in the $w v / w v \mathrm{SN}$, as anticipated. However, identical profiles were also observed within the $\mathrm{SN}$ of the $+/+$ and $+/ w v$ mice, and quantitative analysis of these profiles failed to reveal a consistent difference between $w v / w v$ and the other genotypes. In all three genotypes, a highly significant effect of postnatal age on the prevalence of apoptosis was observed, with many more profiles observed at P14 and very few in adulthood. This temporal pattern 

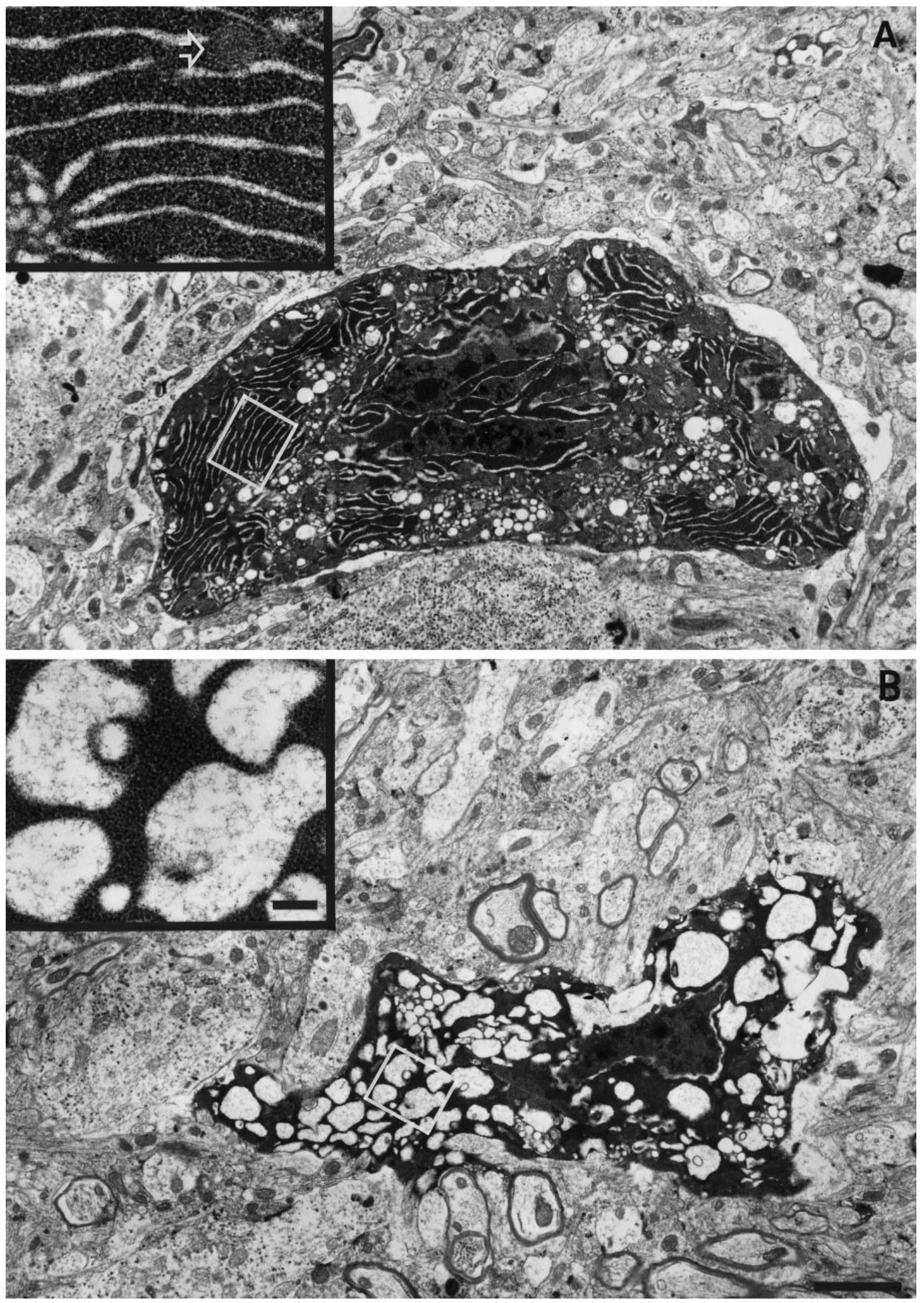

Figure 8. Ultrastructural appearance of degenerating cells in $w v / w v \mathrm{SNpc}$ at $\mathrm{P} 24$. A, This cell is labeled with the number 1 in Figure 7. The nucleus has become invaginated and multilobular. There has been an increase in the intramembranous space of the nuclear membrane. Within the nucleus, there are multiple aggregates of electron-dense chromatin material, which are irregular in size and shape. In the cytoplasm, there are vacuoles and layered structures consisting of dilated cisternae of ER alternating with regions densely packed with ribosomes. An example of these stacks is enclosed within the white box and shown at higher power in the inset. Within the inset, a single representative example of a mitochondrion is marked with an arrow. In general, mitochondria were of normal size and shape, but with increased electron density and poorly defined cristae. In no case were mitochondria dilated. $B$, This cell is labeled with the number 2 in Figure 7. The nuclear changes are like those observed in cell 1 . The predominant cytoplasmic change in cell 2 is the formation of vacuoles. They contained an irregular, sparse electron-dense matrix and were bounded by numerous ribosomes. An example is enclosed in the white box and shown at higher magnification in the inset. Scale bars: $2 \mu \mathrm{m}$ in $A$ and $B ; 200 \mathrm{~nm}$ in the insets. 


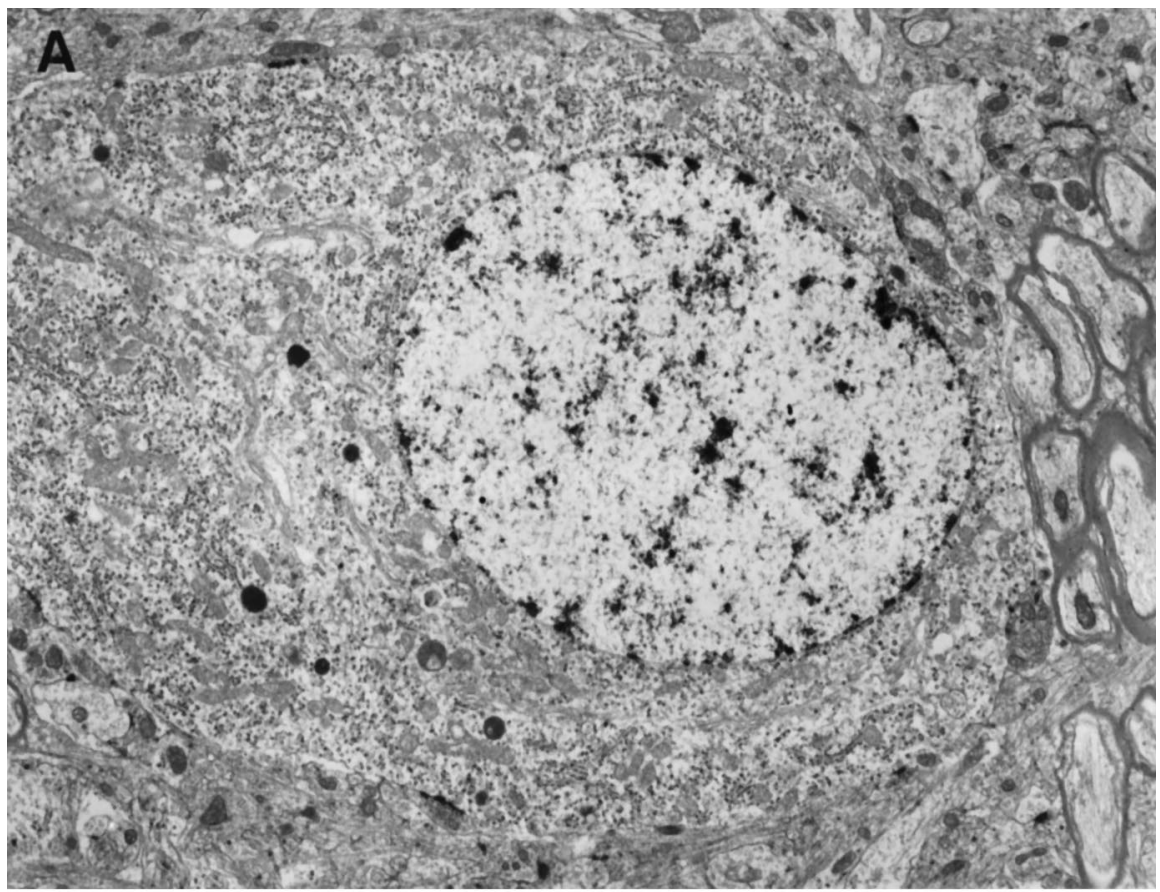

Figure 9. Ultrastructure of normal cells in $w v / w v$ and $+/+$ mice, and a single apoptotic cell in a $+/+$ mouse. $A$, Ultrastructure of a normal neuron in $\mathrm{SNpc}$ of $w v / w v$. This normal-appearing cell contrasts with the pathological features observed in degenerating cells in $w v / w v$, as shown in Figure 8. The nucleus shows multiple, small clumps of heterochromatin, which is characteristic of mouse cells (Moser et al., 1975). Within the cytoplasm, normal-appearing rough ER and mitochondria are observed. $B$, Ultrastructure of a normal neuron in SNpc of $+/+$ mouse. $C$, Abnormal, dense cell in SNpc of a $+/+$ mouse. This cell shows an overall increase in electron density. The nucleus contains a large, rounded, and distinctly bounded chromatin clump. Numerous intact mitochondria are observed in the cytoplasm. We consider these morphological features to be typical of late apoptotic cell death. Thus, this cell confirms the presence of apoptotic profiles observed on silver staining in P24 +/+ mice. Scale bar, $2 \mu \mathrm{m}$ in all panels. Note lower magnification in $C$.
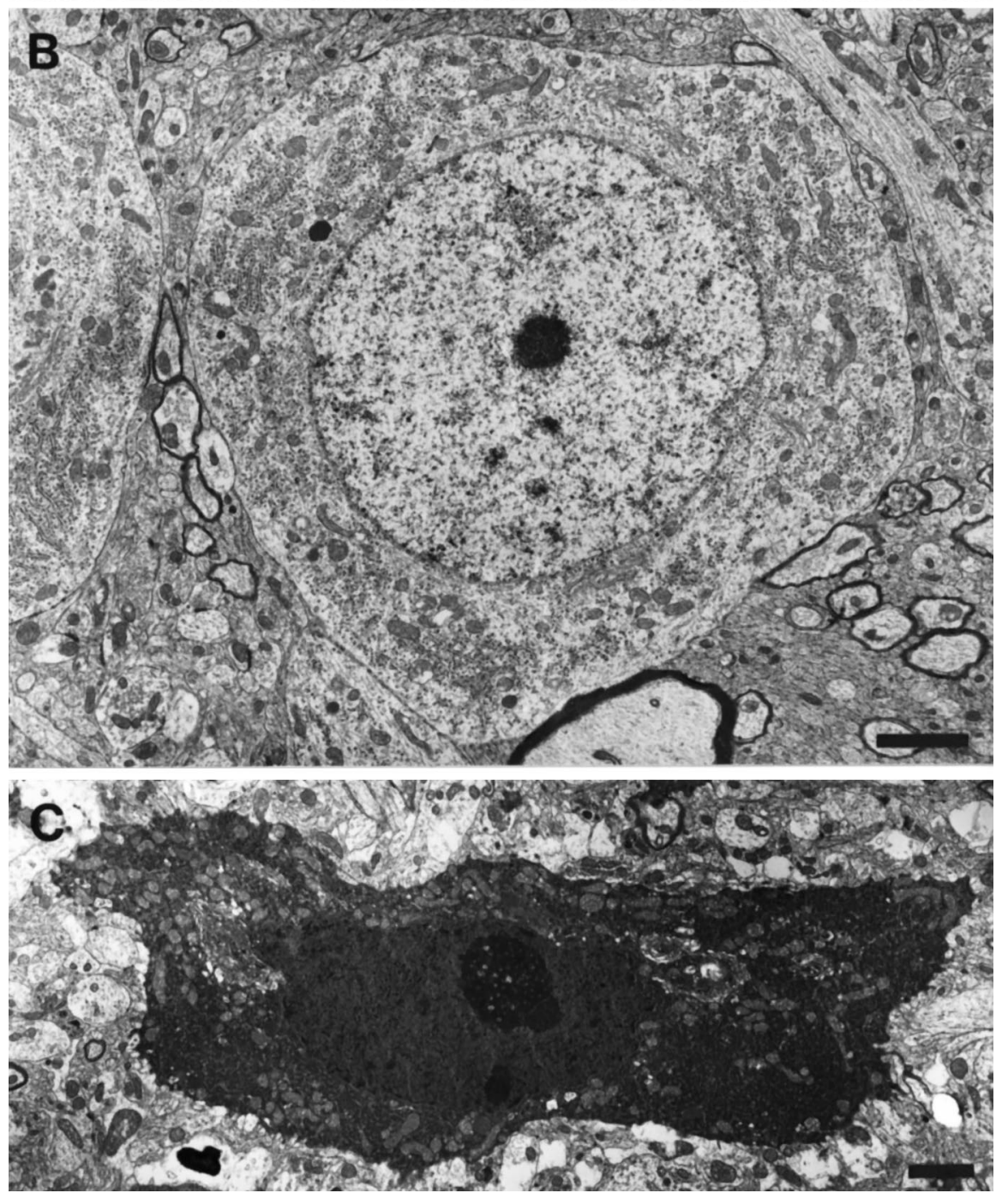


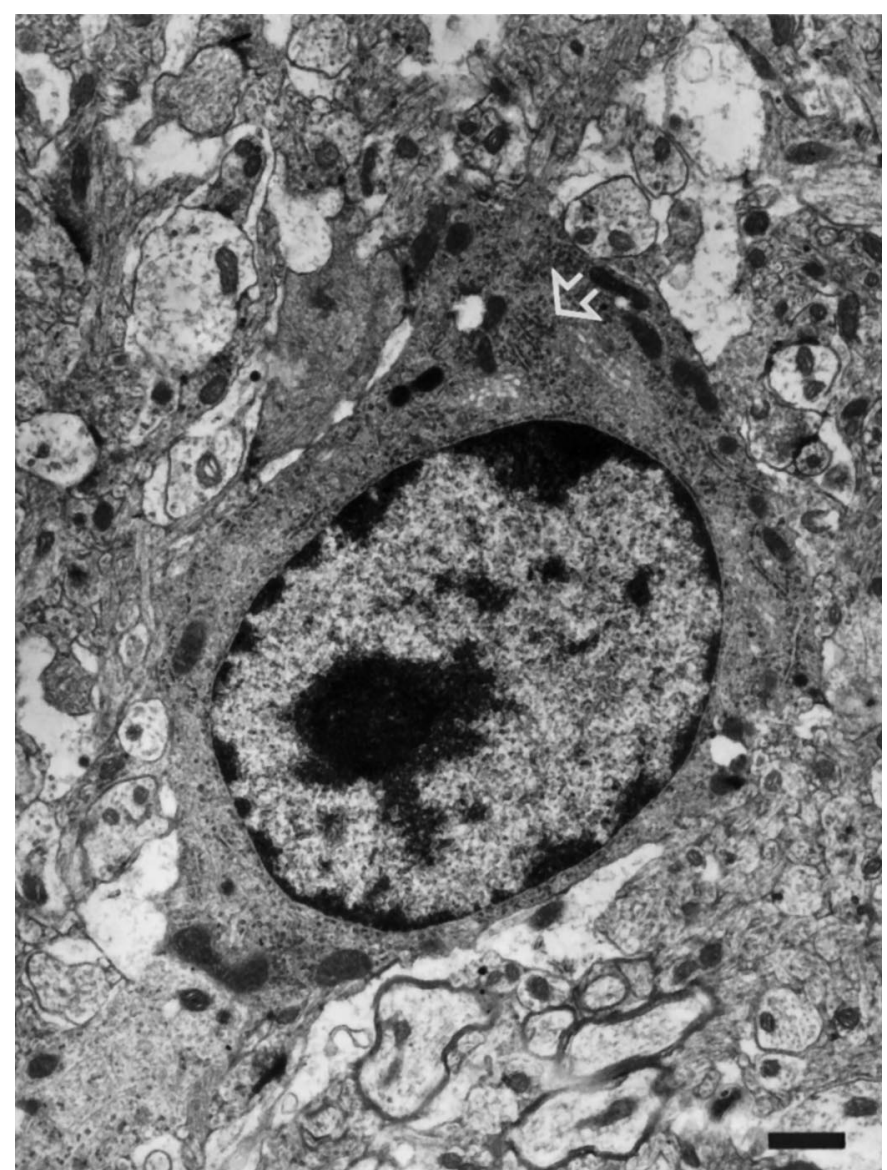

Figure 10. Early ultrastructural changes in a neuron in $\mathrm{SNpc}$ of a $w v / w v$ mouse at P24. Compared with normal SNpc neurons in both $w v / w v$ (Fig. $9 A$ ) and $+/+$ mice (Fig. 9B), this cell shows an increase in the overall electron density. There are abnormal aggregates of nuclear chromatin, both in the central nuclear region and adjacent to the nuclear membrane. These nuclear aggregates are irregular in shape and they do not have distinct boundaries. The nuclear membrane is preserved. Within the cytoplasm, there are many normal-appearing mitochondria. At the upper pole (white arrow), there are abnormal, densely packed clusters of ribosomes accumulating between cisternae of the ER. This change may represent an early phase of the very dense accumulations of ribosomes between ER cisternae observed in cells with a greater degree of degeneration (Fig. $8 A$, inset). Scale bar, $1 \mu \mathrm{m}$.

is quite similar to what we had previously observed for rat, with one peak in the prevalence of apoptotic cells at P14 (Janec and Burke, 1993). Thus, $w v / w v$ does not appear to be associated with a change in the magnitude or timing of a natural cell death event in the SN.

Silver impregnation identified degenerating neurons in $w v / w v$ SN that were not apoptotic by the light microscopic or ultrastructural criteria outlined above. The cellular pattern of silver impregnation observed in $w v / w v$ SN (that of uniform, heavy impregnation of the nucleus and extensive impregnation of the cytoplasm) has been observed in a wide variety of models of induced neuronal degeneration, and does not implicate a single, specific mechanism. We have observed this pattern after direct injection of the neurotoxin 6-hydroxydopamine into the SN (Jeon et al., 1995), and it has been observed in the SN after treatment of mice with the selective dopamine neurotoxin $N$-methyl-4-phenyl-1,2,3,6tetrahydropyridine (MPTP) (Jackson-Lewis et al., 1995). The ultrastructural features observed in the $w v / w v$ cells do not corre-

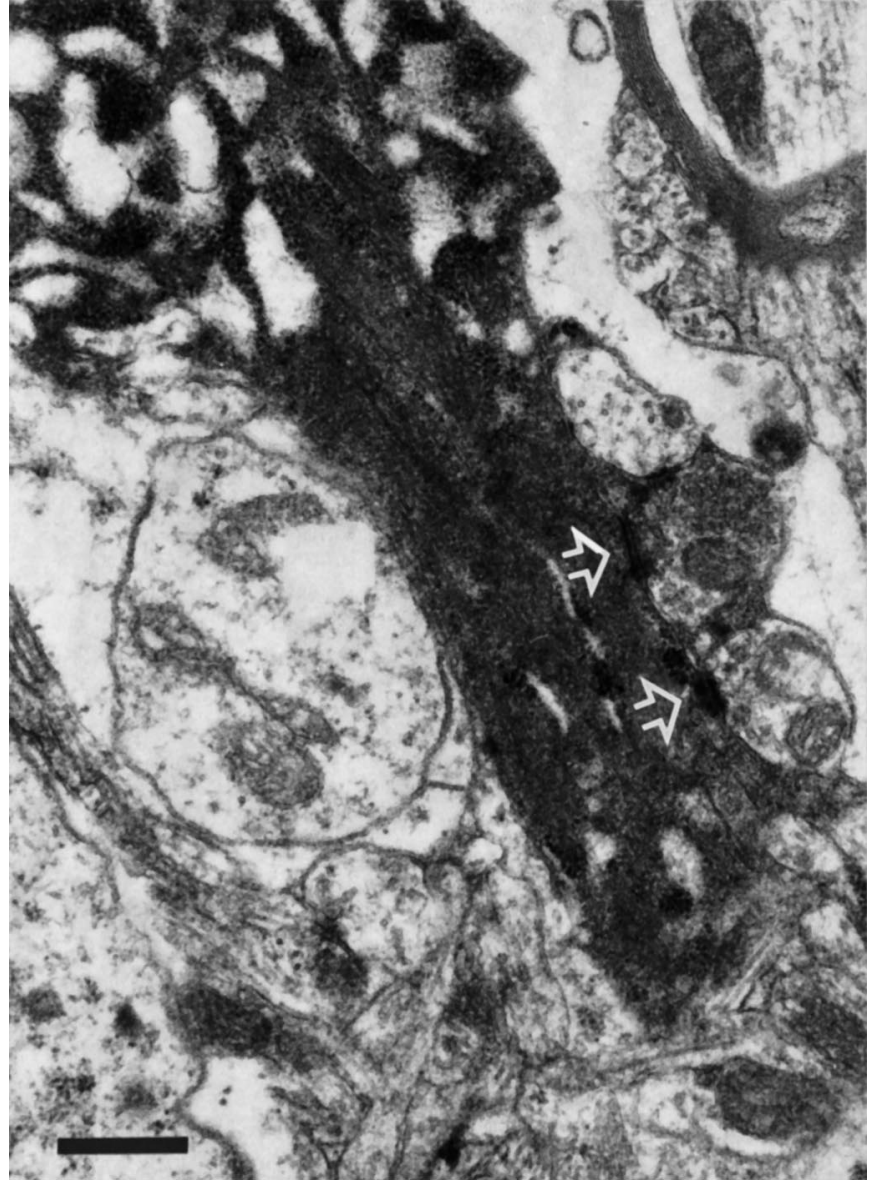

Figure 11. Two synaptic densities (white arrows) are apposed to a degenerating cellular profile in a P24 $w v / w v$ mouse, indicating that the dark cell is a neuron. Scale bar, $500 \mathrm{~nm}$.

spond to the features described for these neurotoxins. 6-hydroxydopamine induces a watery appearance of both the cytoplasm and the nucleus (Ichitani et al., 1994). Although MPTP induces cytoplasmic vacuoles, it does not induce nuclear chromatin aggregates (Mizukawa et al., 1990). MPTP induces mitochondrial dilatation, which does not occur in $w v / w v$ cells. The changes in $w v / w v$ also do not resemble those induced acutely by excitotoxins, which consist of cellular swelling and bloating of mitochondria (Olney, 1969).

Although electron-dense "dark" neurons have been demonstrated to be artifacts attributable to poor fixation (Cammermeyer, 1961), they do not demonstrate the ER stacks we have observed. The dark neuron phenomenon usually reveals a bland, electron-dense appearance, whereas in the $w v / w v$ SN, we observe a spectrum of morphological changes, suggesting an evolving pathological process. Furthermore, morphology such as that observed in $w v / w v$ SN was not seen in $+/+$ controls.

The possibility that the changes we have observed in the $w v / w v$ neurons may represent a late stage in the evolution of the apoptotic process seems unlikely, because in brain, apoptotic cell death is a brief and asynchronous event, so that, at any time, its full morphological spectrum should be evident. Apoptotic profiles in the mice we examined were most abundant at P14, whereas the nonapoptotic morphology was most prevalent at P24-P25. In addition, the morphological features that we observed in the 
$w v / w v$ SN have not been described in other paradigms of apoptosis.

One possible explanation for the morphology that we have observed in $w v / w v \mathrm{SN}$ is that it represents an alternate, nonapoptotic form of developmental cell death. Clark has pointed out that a variety of morphologies can be identified during developmental cell death (Clarke, 1990). His Type 1 category is characterized by nuclear chromatin condensation and corresponds to apoptosis. His Type 3b ("cytoplasmic") resembles the morphology we have observed in $w v / w v$ SN in a number of respects: (1) there is dilatation of the ER and the intranuclear membrane space; (2) some of the vacuoles appear continuous with ER; and (3) there is an abundance of ribosomes. However, in Type 3b, the nuclear changes, especially early in the process, are minimal, whereas in $w v / w v$ we observe clear nuclear chromatin abnormalities even at early stages. Therefore, if this morphology represents an example of Type $3 \mathrm{~b}$ developmental cell death, it must be considered a variant. If this morphology is a variant form of augmented developmental cell death, we must consider why this variant is observed in $w v / w v \mathrm{SN}$, rather than simply an augmented number of cells with an apoptotic morphology. In some developmental settings, the morphology of cell death is related to the maturity of the cell at the time of death (Pilar and Landmesser, 1976; Cunningham, 1982), and maturity may be a factor here. The difference in morphology of the cell death between SN and cerebellum (where it is apoptotic) (Smeyne and Goldowitz, 1989; Migheli et al., 1995; Wullner et al., 1995) may also be related to the maturity of the cells when they die in SN. In SN, how the possibility of augmented developmental cell death relates to the recently described mutation in the GIRK2 potassium channel in weavers (Patil et al., 1995) is unknown.

An alternative interpretation of our results is that cell death in $\mathrm{SN}$ represents a pathological morphology attributable to cell injury mediated by the GIRK2 mutation. Recent functional studies of the effect of the weaver mutation on the GIRK2 channel have suggested that it leads to a loss of selectivity for the $\mathrm{K}^{+}$ion (Slesinger et al., 1996) and, in cerebellar granule cells, this leads to a constitutive, depolarizing inward $\mathrm{Na}^{+}$current (Kofuji et al., 1996). If the mutation results in an aberrant sodium current that depolarizes the cell, this may lead to a chronic, excitotoxic form of neuron death that may differ from that described for acute excitotoxicity (Olney, 1969). Whether the cell death in $w v / w v \mathrm{SN}$ is augmented developmental cell death, as considered above, or strictly a pathological degenerative process, it may in either case involve the mechanisms of programmed cell death, defined in the broadest sense as a genetically regulated death process.

There is an apparent discrepancy between our observation that the largest number of nonapoptotic profiles appeared at P24-P25 and the previous observation that most of the TH-positive neurons have been lost by P21 in $w v / w v$ animals (Roffler-Tarlov et al., 1996). One possible explanation for this discrepancy is that the TH-positive neurons are dysfunctional and have lost their expression of TH before the onset of degeneration, as identified by silver staining and ultrastructure. In favor of this possibility is our observation that abnormal cells could be demonstrated on Nissl stain at P24-P25, and yet these cells did not express TH. Also in support of this possibility is the fact that the TH-positive neurons are known to be abnormal even before they lose their phenotypic expression of $\mathrm{TH}$; at $\mathrm{P} 7$, their neuritic extensions into SNpr are abnormal (Roffler-Tarlov et al., 1996). It is also possible that we have missed a higher peak of cell death in SNpc between P14 and $\mathrm{P} 24-\mathrm{P} 25$, and what we observe at $\mathrm{P} 24-\mathrm{P} 25$ reflects the continued loss of TH-positive neurons (Roffler-Tarlov et al., 1996).
Whatever the pathogenesis of dopamine neuron degeneration in $w v / w v$, it is a late developmental event. At this developmental time, these neurons are postmitotic, postmigratory, and they probably are also beyond the period of target dependence, based on target ablation studies in developing rat (our unpublished observations). The degeneration in $\mathrm{SN}$ may be related to the late development of a system property, such as the arrival of synaptically active afferent input. In rat, the developmental period showing the greatest rate of increase in number of synaptic profiles per cell in the SNpc is P15-P30 (Lauder and Bloom, 1975), which corresponds to the period of maximal cell death in $\mathrm{SNpc}$ in $w v / w v$.

\section{REFERENCES}

Abercrombie M (1946) Estimation of nuclear populations from microtome sections. Anat Rec 94:239-247.

Cammermeyer J (1961) The importance of avoiding "dark" neurons in experimental neuropathology. Acta Neuropathol (Berl) 1:245-270.

Clarke PGH (1990) Developmental cell death: morphological diversity and multiple mechanisms. Anat Embryol (Berl) 181:195-213.

Clarke PGH, Oppenheim RW (1995) Neuron death in vertebrate development: in vivo methods. In: Methods in cell biology: cell death (Schwartz LM, Osborne BA, eds), pp 277-321. New York: Academic.

Coggeshall RE (1992) A consideration of neural counting methods. Trends Neurosci 15:9-13.

Coggeshall RE, Lekan HA (1996) Methods for determining numbers of cells and synapses: a case for more uniform standards of review. J Comp Neurol 364:6-15.

Cunningham TJ (1982) Naturally occurring neuron death and its regulation by developing neural pathways. Int Rev Cytol 74:163-186.

Ferrer I, Bernet E, Soriano E, del Rio T, Fonseca M (1990) Naturally occurring cell death in the cerebral cortex of the rat and removal of dead cells by transitory phagocytes. Neuroscience 39:451-458.

Gallyas F, Wolff JR, Bottcher H, Zaborsky L (1980) A reliable and sensitive method to localize terminal degeneration and lysosomes in the central nervous system. Stain Technol 55:299-306.

Gavrieli Y, Sherman Y, Ben-Sasson SA (1992) Identification of programmed cell death in situ via specific labeling of nuclear DNA fragmentation. J Cell Biol 119:493-501.

Graybiel AM, Ohta K, Roffler-Tarlov S (1990) Patterns of cell and fiber vulnerability in the mesostriatal system of the mutant mouse weaver. J Neurosci 10:720-733.

Gundersen HJG (1986) Stereology of arbitrary particles. J Microsc $143: 3-45$

Harrison SMW, Roffler-Tarlov S (1995) Apoptotic and non-apoptotic cell death in the mouse mutant weaver. Soc Neurosci Abstr 424:16.

Ichitani Y, Okamura H, Nakahara D, Nagatsu I, Ibata Y (1994) Biochemical and immunocytochemical changes induced by intrastriatal 6-hydroxydopamine injection in the rat nigrostriatal dopamine neuron system: evidence for cell death in the substantia nigra. Exp Neurol 130:269-278.

Jackson-Lewis V, Jakowec M, Burke RE, Przedborski S (1995) Time course and morphology of dopaminergic neuronal death caused by the neurotoxin 1-methyl-4-phenyl-1,2,3,6,-tetrahydropyridine. Neurodegen 4:257-269.

Janec E, Burke RE (1993) Naturally occurring cell death during postnatal development of the substantia nigra of the rat. Mol Cell Neurosci 4:30-35.

Jeon BS, Jackson-Lewis V, Burke RE (1995) 6-Hydroxydopamine lesion of the rat substantia nigra: time course and morphology of cell death. Neurodegen 4:131-137.

Kerr JF, Wyllie AH, Currie AR (1972) Apoptosis: a basic biological phenomenon with wide-ranging implications in tissue kinetics. $\mathrm{Br} \mathrm{J}$ Cancer 26:239-257.

Kerr JFR, Gobe GC, Winterford CM, Harmon BV (1995) Anatomical methods in cell death. In: Methods in cell biology: cell death (Schwartz LM, Osborne BA, eds), pp 1-27. New York: Academic.

Kofuji P, Hofer M, Millen KJ, Millonig JH, Davidson N, Lester HA, Hatten ME (1996) Functional analysis of the weaver mutant GIRK2 $\mathrm{K}^{+}$channel and rescue of weaver granule cells. Neuron 16:941-952.

Lane JD, Nadi NS, McBride WJ, Aprison MH, Kusano K (1977) Contents of serotonin, norepinephrine and dopamine in the cerebrum of the "staggerer," "weaver" and "nervous" neurologically mutant mice. J Neurochem 29:349-350. 
Lauder JM, Bloom FE (1975) Ontogeny of monoamine neurons in the locus coeruleus, raphe nuclei and substantia nigra of the rat. J Comp Neurol 163:251-264.

Macaya A, Munell F, Gubits RM, Burke RE (1994) Apoptosis in substantia nigra following developmental striatal excitotoxic injury. Proc Natl Acad Sci USA 91:8117-8121.

Migheli A, Attanasio A, Lee W-H, Bayer SA, Ghetti B (1995) Detection of apoptosis in weaver cerebellum by electron microscopic in situ end-labeling of fragmented DNA. Neurosci Lett 199:53-56.

Mitchell IJ, Lawson S, Moser B, Laidlaw SM, Cooper AJ, Walkinshaw G, Waters CM (1994) Glutamate induced apoptosis results in a loss of striatal neurons in the parkinsonian rat. Neuroscience 63:1-5.

Mizukawa K, Sora YH, Ogawa N (1990) Ultrastructural changes of the substantia nigra, ventral tegmental area and striatum in 1-methyl-4phenyl-1,2,3,6-tetrahydropyridine (MPTP)-treated mice. Res Commun Chem Pathol Pharmacol 67:307-320.

Moser FG, Dorman BP, Ruddle FH (1975) Mouse-human heterocaryon analysis with a 33258 Hoechst-Giemsa technique. J Cell Biol 66:676-680.

Olney JW (1969) Glutamate-induced retinal degeneration in neonatal mice. Electron microscopy of the acutely evolving lesion. J Neuropathol Exp Neurol 28:455-474.

Oo TF, Henchcliffe C, Burke RE (1995) Apoptosis in substantia nigra following developmental hypoxic-ischemic injury. Neuroscience 69:893-901.

Patil N, Cox DR, Bhat D, Faham M, Myers RM, Peterson AS (1995) A potassium channel mutation in weaver mice implicates membrane excitability in granule cell differentiation. Nat Genet 11:126-129.

Pilar G, Landmesser L (1976) Ultrastructural differences during embryonic cell death in normal and peripherally deprived ciliary ganglia. J Cell Biol 68:339-356.

Rakic P, Sidman RL (1973) Sequence of developmental abnormalities leading to granule cell deficit in cerebellar cortex of weaver mutant mice. J Comp Neurol 152:103-132.

Rezai R, Yoon CH (1972) Abnormal rate of granule cell migration in the cerebellum of "weaver" mutant mice. Dev Biol 29:17-26.

Roffler-Tarlov S, Graybiel AM (1984) Weaver mutation has differential effects on the dopamine-containing innervation of the limbic and nonlimbic striatum. Nature 307:62-66.

Roffler-Tarlov S, Graybiel AM (1986) Expression of the weaver gene in dopamine-containing neural systems is dose-dependent and affects both striatal and nonstriatal regions. J Neurosci 6:3319-3330.

Roffler-Tarlov S, Graybiel AM (1987) The postnatal development of the dopamine-containing innervation of dorsal and ventral striatum: effects of the weaver gene. J Neurosci 7:2364-2372.
Roffler-Tarlov S, Turey M (1982) The content of amino acids in the developing cerebellar cortex and deep cerebellar nuclei of granule cell deficient mutant mice. Brain Res 247:65-73.

Roffler-Tarlov S, Pugatch D, Graybiel AM (1990) Patterns of cell and fiber vulnerability in the mesostriatal system of the mutant mouse weaver. II. High affinity uptake sites for dopamine. J Neurosci 10:734-740.

Roffler-Tarlov S, Martin B, Graybiel AM, Kauer JS (1996) Cell death in the midbrain of the murine mutation weaver. J Neurosci 16:1819-1826.

Schmidt MJ, Sawyer BD, Perry KW, Fuller RW, Foreman MM, Ghetti B (1982) Dopamine deficiency in the weaver mutant mouse. J Neurosci 2:376-380.

Schwartz LM, Smith SW, Jones MEE, Osborne BA (1993) Do all programmed cell deaths occur via apoptosis? Proc Natl Acad Sci USA 90:980-984.

Sidman RL, Green MC, Appel SH (1965) Catalog of the neurological mutants of the mouse. Cambridge: Harvard UP.

Slesinger PA, Patil N, Liao J, Jan YN, Jan LY, Cox DR (1996) Functional effects of the mouse weaver mutation on $G$ protein-gated inwardly rectifying $\mathrm{K}^{+}$channels. Neuron 16:321-331.

Sloviter RS, Dean E, Neubort S (1993) Electron microscopic analysis of adrenalectomy induced hippocampal granule cell degeneration in the rat: apoptosis in the adult central nervous system. J Comp Neurol 330:337-351.

Smeyne RJ, Goldowitz D (1989) Development and death of external granular layer cells in the weaver mouse cerebellum: a quantitative study. J Neurosci 9:1608-1620.

Tischler AS (1995) Triple immunohistochemical staining for bromodeoxyuridine and catecholamine biosynthetic enzymes using microwave antigen retrieval. J Histochem Cytochem 43:1-4.

Triarhou LC, Norton J, Ghetti B (1988) Mesencephalic dopamine cell deficit involves areas A8, A9 and A10 in weaver mutant mice. Exp Brain Res 70:256-265.

Williams RW, Rakic P (1988) Elimination of neurons from the rhesus monkey's lateral geniculate nucleus during development. J Comp Neurol 272:424-436.

Wullner U, Loschmann PA, Weller M, Klockgether T (1995) Apoptotic cell death in the cerebellum of mutant weaver and lurcher mice. Neurosci Lett 200:109-112.

Yamamoto T, Iwasaki Y, Konno H, Iizuka H (1986) Identification of cells undergoing physiological neuronal death in the neonatal rat brain by the Fink-Heimer method. Brain Res 374:419-424. 